\title{
The re-birth of Shakespeare in India: celebrating and Indianizing the Bard in $1964^{1}$
}

\author{
Rosa M. García-Periago \\ Universidad de Murcia
}

\begin{abstract}
While the Tercentenary of Shakespeare's death (1916) was hardly celebrated in India and marked the beginning of a period in which Shakespeare was hidden, the Quartercentenary of his birth (1964) spawned a large number of collections, theatre performances and even exhibitions to pay homage to the Bard. Although a special issue of the journal Indian Literature published in 1964 contributed to the re-emergence of Shakespeare, the most revolutionary projects in the making of a vernacular Shakespeare occurred on the Indian stage via Utpal Dutt's Shakespearean productions in Bengali. Following Arjun Appadurai, this paper argues that Utpal Dutt's Bengali theatre productions in 1964 participate in a "decolonization" of Shakespeare, consisting in liberating Shakespeare "the text" and Shakespeare "the author" from the bonds of the empire, from restrictive colonial associations. Two out of his three theatre performances produced in 1964 - Romeo and Juliet and Julius Caesar - are symptomatic of the effects of "glocalizing" the Shakespearean texts since the original place names and names of the characters are combined with the Bengali language and some unavoidable localization. Thus, Shakespeare's Quartercentenary in India not only saw the re-emergence of the Bard, but also took its first steps in his indigenization.
\end{abstract}

KEYWORDS: Shakespeare, appropriation, theatre performances, Quartercentenary, India.

${ }^{1}$ This article is part of the project FFI2011-24347 "Cultures of Commemoration II: Remembering Shakespeare" funded by the Spanish Ministerio de Ciencia e Innovación (MICINN). 
The special number of the journal Indian Literature published in 1964 by the Sahitya Akademi to commemorate Shakespeare's birthday includes an advertisement which deploys both Shakespeare's iconic image as writer and his words to market aluminium. The advertisement (Illustration 1) features a prolific Shakespeare, quill in hand, accompanied by the well-known quotation from Romeo and Juliet "what's in a name?" The choice of play is not random, for it is the most celebrated in India. The advertisement rests on the assumption that Shakespeare is the icon of high culture par excellence. Given that the commercial is included in a special number devoted to Shakespeare, the implication is that those who read Shakespeare can afford aluminium instead of copper. While the cultural manifestations - ranging from cartoons to musical sketches or stamps - to commemorate the Quartercentenary in the Anglophone world entail a confrontation between high culture and low culture, in India, Shakespeare embodies a certain elitism. Yet, at the same time, the commercial effectively toys with the Shakespearean citation quoted at the outset, and (mis)interprets - or rather, reinterprets transliterates or appropriates it for the aluminium brand it helps to market. If the "what's in a name" speech basically suggests the lack of importance of having a specific name (or surname), the advertisement contradicts such a statement. After the Romeo and Juliet quotation ("that which we call a rose, by some other name would smell as sweet"), the text reads ironically "perhaps, but not quite." The ending does not preserve western heritage literally, but changes the intended Shakespearean meaning completely since it emphasizes the weight of a name ("A name is not just an identifying tag - a name carries with it a company's reputation"). Like in this Aluminium Shakespeare commercial, a Budweiser Shakespeare ad published in 1936 contradicts the well-known Romeo and Juliet quotation, and highlights the importance of the name Budweiser to refer to the best ale. Although the image of Shakespeare dominates both illustrations, the advertising strategy used in both consists in the considerable distance from Shakespeare's authority even as the advertisements "draw upon the reader's passing familiarity with phrases from his (Shakespeare's) work" (Lanier 2012:508). ${ }^{2}$ Even if

\footnotetext{
${ }^{2}$ See Lanier (2012:499-515) for a thorough discussion of the role Shakespeare has played in the world of brands and advertising. He distinguishes three different periods in his paper (1875-1900; 1900-1960 and 1960 to the present).
} 
the meaning is not unquestionably swallowed but appropriated in the commercial, the western author still has a high culture "aura." At the same time, the advertisements equally seem to point out that Shakespearean works are deeply involved in discourses of western capitalism; so, the recirculation of Shakespearean texts after a period of absence may be far from innocent. However, as this paper will argue, Shakespeare's name extended its meaning in India in 1964 beyond western capitalism, and was equally inserted in Indian popular culture.

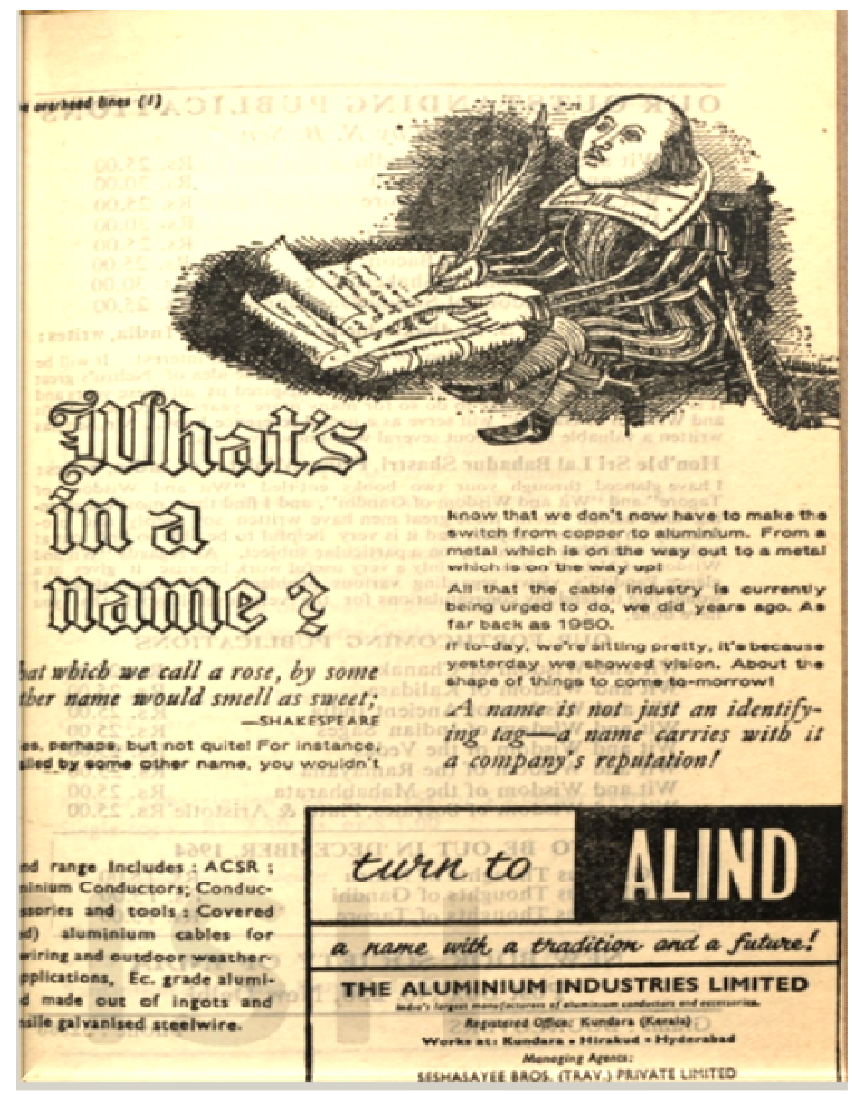

Illustr. 1. Aluminium advertisement in which Shakespeare is the "star" to market it. Reproduced by permission of Sahitya Akademi.

The main purpose of this essay is to find out and explore how Indians commemorated Shakespeare's Quartercentenary and suggest that this year marks the beginning of a new era for the 
interpretation of Shakespeare's works in India. After a period in which Shakespeare was absent, the post-colonial Indian nation recuperates the plays - in spite of their previous colonial associations - possibly as a result of the world-wide drive to celebrate Shakespeare in 1964. The Indian "fidelity" to Shakespeare is revived this year via special journals and books as well as performances directed by Utpal Dutt, who was the perfect bridge between Shakespeare and the Indian layman in the street. Utpal Dutt was convinced that Shakespearean plays had the qualities to target both Bengali middle classes and the common man; he endeavored to familiarize the masses with the Shakespearean oeuvre and to negotiate the distance between the Bengali language and the Shakespearean script. Utpal Dutt deliberately revitalized Shakespearean plays in Bengali to confirm his rejection of the highbrow Shakespeare and his western capitalism connotations in a year - 1964 - which witnessed the split of the Communist Party of India into two sections, one of them (strongly supported by Utpal Dutt) with clearly Marxist allegiances. The re-interpretation of Shakespearean plays in Bengali was Dutt's first step to subtly favor the recently founded Communist Party of India (Marxist), characterized by its anti-capitalism. This paper argues that the celebrations of the 4ooth anniversary of Shakespeare's birth in India are symptomatic of the change concerning Shakespeare's reception in this period for, although some still consolidate the Bardic image as a western icon linked to high-brow culture and western capitalism, the majority of them assumed Shakespeare's reconstruction as an icon for the masses. In 1964, the vernacularization or indigenization of Shakespeare was on the move.

\section{The Death of the Author}

One of the most intriguing cases of the Indian encounters with Shakespeare is the "dark" stage or period of absence - from the 1910 s to the 1950 - in which Shakespearean performances and productions declined considerably. China also witnessed a period of absence and disappearance of Shakespearean plays (Li 2003:24). For some time, Shakespeare appeared to have been obliterated. While the Japanese commemorated Shakespeare's 1916 Tercentenary with contributions in book form such as Shakespeare: His Life and Works (dedicated to John Lawrence, the architect that promoted the 
Japanese familiarization with Shakespeare), there are no records of special collections or books in India to pay homage to the author (Anzai, Iwasaki and Milward 1999:17). Furthermore, famous performances of Shakespearean plays are not recalled either. The 1916 Tercentenary of Shakespeare's death went completely unnoticed in India, and this year witnessed an epistemic break with the Shakespearean industry.

The pre-existing framework in which Shakespeare was tied to the presence of British colonialism explains the process of "decolonization" undergone by Shakespeare and accounts for his absence in Indian culture in this period. According to Poonam Trivedi and Dennis Bartholomeusz (2006:17), S. K. Bhattacharya (1964:34) and Charles Sisson (1926:16), the strengthening of the nationalist movement paralyzed the ascendance of the Shakespearean productions. In order to rebuild the nation-state, the colonial shreds or patches were dramatically removed. India had to be reconstructed from within by reforming the nation's outlook, which included Shakespeare - regarded as a palpable threat to India's national sovereignty. The Indian intellectuals and intelligentsia were also affected, and could not continue boosting their fascination with Shakespeare. Sunita Paul (1989:20) equally agrees on the hostility to colonial rule as a direct cause of the oblivion of Shakespeare. While Sunita Paul lists a total of 434 translations from the nineteenth century onwards, only fifty adaptations belonging to 1920-1947 are mentioned (1989:20). Concerning performances, only a selection of scenes from Othello translated by Debendranath Basu and from Macbeth translated by Girish Chandra Ghose (performed on 22 September 1926 and 29 September 1926 respectively) are worth mentioning.

Interest in Shakespeare's plays strongly declined for several years. Scholars do not agree on the date of the start of the decline and subsequent revival of Shakespeare in India. Charles Sisson (1926:16) establishes the point of departure from Shakespeare after 1912 as a clear reaction against English literature and culture. For Harish Trivedi (1995:14), the debunking of Shakespeare began in the aftermath of World War I as a direct consequence of the spread of "Gandhian" nationalism. Similarly, for Jyotsna Singh (1996:141), the repertoire of Shakespearean plays began to be substituted by Bengali plays in 1920 as part of the nationalistic project. For Singh, 
Shakespeare re-emerged in 1940 (1995:141), whereas for Trivedi and Bartholomeusz (2006:17) the real turning point was 1947, the year in which India got its independence.

Although Shakespeare's revival started in the post-colonial period, it was still considered a western import of artistic exotica, and the link with colonialism was reinforced. Norman Marshall toured India in 1948 with a company of actors staging Shakespeare's plays. He hinted at an imperial past in which Shakespearean plays were subordinated to the colonial power, for the plays were performed by English actors for an Indian audience. The spectre of British imperialism also haunted the performances by Geoffrey and Laura Kendal. Their connection with Shakespeare comes under scrutiny in their second (1947-1948) and third (1953-1956) trips to India when they toured the country with their "Shakespeareana" company with a total of 879 performances of Shakespeare's plays and other English classics. This company of Anglo-Indians did not extend its boundaries beyond western culture, for the performances were in English for the educated Indians. Even on screen, the Shakespearean industry operated on the assumptions of western superiority. Kishore Sahu's Hamlet (1954) was visualized shot-byshot as Laurence Olivier's Hamlet (1948), and the imagery, setting and ambiance imitated, or rather mimicked the western production. Although the re-emergence of Shakespeare in India already started just after their independence from the British, the re-birth of a vernacular Indian Shakespeare was in fact materialized in 1964 through the tradition of the Parsi theatre, as will be discussed below. ${ }^{3}$

\section{Shakespeare in Print in 1964}

While in China the commemorations for the $400^{\text {th }}$ anniversary of Shakespeare's birth were cancelled since the "sky darkened and the political weather changed considerably" (Levith 2004:40) and Shakespeare was synonymous with western capitalism - as the

\footnotetext{
3 Parsi theatre can be considered the first modern commercial theatre, highly influential between the 1850 s and 1930s. Parsi theatre was an in-between, hybrid project, for it was subsidized by the Parsis - the Zoroastrian community - but added European techniques to its performances. See for instance Lal (2009:102-108).
} 
Alind and Budweiser advertisements proved - in India, an interesting discourse on and about Shakespeare emerged. ${ }^{4}$ Several publications that came to light in 1964 are all fraught with ambivalence regarding the role of Shakespeare. Some volumes follow the path of colonial publications flattering and praising Shakespeare in English. Other publications are interestingly concerned with the appropriation of the plays in Indian languages.

C. D. Narasimhaiah, a well-known member of the Indian Academy, compiled a volume of essays which had the purpose of extolling Shakespeare's role within the Indian subcontinent. The lasting association between Shakespeare and colonialism makes its star appearance at the very outset of the collection: "for the England of trade, commerce, imperialism and the penal code has not endured but the imperishable Empire of Shakespeare will always be with us. And that is something to be grateful for" (Narasimhaiah 1964:v). Including articles with provoking titles such as "Has Shakespeare fallen on evil tongues?" or "Why Shakespeare for us?" the collection adopts a very old-fashioned approach, since it highlights that the Indians cannot do without their Shakespeare in English, and criticizes the translation into Indian languages. With a constantly disturbing and condescending tone, the volume asserts that "even the average Indian student is responsive to poetry" (Narasimhaiah 1964:5). The intellectuals' admiration for Shakespeare is linked with their apparent acquisition of a status symbol. Sixteen years after independence, elite Indians still believed that the loss of Britain would be compensated by the ongoing presence of Shakespeare. This book is not affected by political crises, and still sails in comfortable colonial waters.

The special issue of the journal Indian Literature devoted to Shakespeare's 1964 Quartercentenary moved significantly away from the previous approach. The editors' main aim and purpose was to explore the experience of doing Shakespeare on the Indian stage for English readers. They wanted to promote the possibility of a

\footnotetext{
${ }^{4}$ Chen Jia was actually one of the few who dared to perform Shakespeare. He and his Nanjing University students acted several scenes from King Lear, The Merchant of Venice, or Hamlet in English. The main consequence of such a bold act was public humiliation. See Levith (2004:40) or Li (2003:50).
} 
proper encounter between India and Shakespeare. ${ }^{5}$ For instance, S. $\mathrm{K}$. Bhattacharya explained the intricacies of Shakespeare and Bengali Theatre and Chandravadan C. Mehta explored the reception of Shakespeare on the Gujarati stage. Given that "language became the deciding factor in the decline of the English plays and the development of a vigorous Bengali theatre" (Bhattacharya in Singh 1996:453), Shakespearean plays had to be adapted first to be subsequently staged on the Bengali stage. Throughout his chapter, S. $\mathrm{K}$. Bhattacharya confirms that Shakespeare was the most crucial influence in the development of Bengali theatre. The reception of Shakespeare's works follows a similar trajectory in Gujarati theatre, in which extremely free adaptations were the rule. Apart from the presence of Shakespeare in some Indian theatres, the special collection equally includes Shakespeare's presence in other Indian languages (Assamese, Hindi, Karnataka, Malayalam, Marathi, Oriya, Punjabi, Sanskrit, Sindhi, Tamil, Telugu and Urdu). This special issue is remarkable for its scale and variety - including a significant range of Shakespearean manifestations in Indian theatres and in Indian languages - and also for being unique in its purpose. There was a sustained interest in transforming Shakespeare into a hybrid identity. This special issue of Indian Literature takes a step forward regarding the hitherto forgotten possibilities of Shakespeare in new Indian sites and languages. These two very different publications C. D. Narasimhaiah's book and the Indian Literature journal - are symptomatic of the ambivalence towards Shakespeare in literary manifestations that appeared in India in 1964. Although the journal is only a pioneering attempt in print to vernacularize Shakespeare, "the grip of the colonial "civilizing mission" is "loosened" on the Indian stage (Singh 1996:136). The creation of the horizon of expectations re-emerges with Utpal Dutt.

\footnotetext{
${ }^{5}$ There were other publications in 1964. Oxygen News dedicated a special number to Shakespeare (Kolkata, 1964). There was also an exhibition catalogue entitled Shakespeare in India at the National Library, Kolkata. See the bibliography "Shakespeare in India" at the website Internet Shakespeare editions: url: http:/ /internetshakespeare.uvic.ca/Library/Criticism/shakespearein/india7.html. (Last accessed 07/08/2011).
} 


\section{The Making of an Icon on the Indian Stage}

In the scenario of post-colonial India, the year 1964 saw the beginning of the "vernacularization" of Shakespeare on the Indian stage, signalling the onset of the decolonization of Shakespeare. Decolonization in India affected "every domain of public life, from language and the arts to ideas about political representation and economic justice" (Appadurai 1996:89). Arjun Appadurai for instance concentrates on the decolonization of cricket in India. The "indigenization" of cricket has a wide range of dimensions, such as the publicity, management and patronization of the sport, the capacity of Indians to imitate and mimic Victorian elite values, as well as the necessity to deprive cricket of the corrosive bonds of England - amongst many others. As cricket ought to be liberated from its Englishness, the English terminology had to be substituted by the corresponding jargon in Marathi, Tamil, Hindi or Bengali for instance. The main difference between the "vernacularization" of cricket and that of Shakespeare is that while the former has been completely deprived of its English habitus and has become a national sport, the latter's decolonization is still an ongoing process. Yet, superimposing the "vernacularization" of cricket to that of Shakespeare many similarities emerge. Although both entered the Indian subcontinent via the English language, they were translated into the diverse Indian languages. Both have always carried a certain elitist flavour. Yet, cricket "dictated an openness to talent and vocation in those of humble origin," (Appadurai 1996:92) just as Shakespearean performances attracted audiences from poor backgrounds. Interestingly, this approach to Indian audiences was possible in both cases thanks to the Parsis, who acted as a liaison between English and Indian cultural tastes. In the specific case of Parsi Shakespearean adaptations, crucial attempts at crossing cultural borders were made in order to address Indian audiences. Amongst other significant changes in the Parsi Shakespearean adaptations with regard to the source texts, the plots were reduced, additions were provided, songs and dances were included lengthening the theatre productions considerably. ${ }^{6}$ These Parsi adaptations were then the first theatrical experiments to contain a very different dimension of Shakespeare. Parsis mimicked and

\footnotetext{
${ }^{6}$ For a complete and detailed study of Parsi theatre, see Gupta (2005).
} 
imitated the western canon provided by the English colonizers but, at the same time, contributed to a new and challenging way of understanding Shakespeare. Parsi theatre did not do Shakespeare in English, but in a vernacular Indian language. These adaptations were "almost the same, but not quite" (Bhabha 1994:122). They certainly implied a double articulation or ambivalence of conflicting ideologies. Yet, after the dark period of absence of Shakespeare in India and the independence of the country, the "resurrection" and re-emergence of Shakespeare and his real decolonization or indigenization is immediately connected with Utpal Dutt and Shakespeare's Quartercentenary. Besides, the making of Shakespeare as an Indian icon by Dutt also aims to subtly favor the political ideology of the Communist Party of India (Marxist). The decolonization of Shakespeare in India started by Utpal Dutt aimed to change his appearance as well as the meanings of his plays by taking considerable distance from the typical connotations of western capitalism.

Utpal Dutt began his theatrical career with amateur productions of Shakespeare's plays at St. Xavier's College, such as Hamlet (1943). Drama at St Xavier's College in Calcutta was extremely influential, and contributed significantly to the performance of Shakespeare in India. At St. Xavier's, Dutt was discovered by Geoffrey and Jennifer Kendal and joined them in their Shakespeareana Company touring India and Pakistan in 1947-1948 and 1953-1954 on a professional basis. ${ }^{7}$ The temporal gap between the first and second tours was related to the Kendals' departure to England. Utpal Dutt performed the roles of Antonio in The Merchant of Venice, Mercutio in Romeo and Juliet, Ross in Macbeth and Decius Brutus in Julius Caesar. ${ }^{8}$ While the lure of the British Empire looms large in these productions, Tapati Gupta suggests that their

\footnotetext{
${ }^{7}$ Geoffrey and Laura Kendal (née Laura Liddell) were the leaders and managers of a theatre company called "Shakespeareana," which toured all over India mostly during WWII. Their audience was extremely significant and diverse, for they could perform in front of royalty or in front of schoolchildren. Their trajectory can be seen in Shakespeare Wallah (dir. James Ivory and Ismael Merchant, 1965), and was also accounted by Geoffrey Kendal himself in The Shakespeare Wallah: The Autobiography of Geoffrey Kendal (London: Sidgwick \& Jackson, 1986).

${ }^{8}$ For a comprehensive list of Utpal Dutt's performances and roles in different languages (English, Bengali) or in other theatrical traditions (jatra, for instance), see Paul (2006).
} 
construction is actually based on mimicry (Gupta 2010:159). The verisimilitudes of the productions with the English performances were apparent, but they still had a quality to them and displayed theatrical sensibilities which differed considerably from the Shakespearean adaptations performed in the Anglophone world. Utpal Dutt later founded the troupe Amateur Shakespeareans, which was renamed Little Theatre Group, in which they produced many Shakespearean plays in English, such as A Midsummer Night's Dream, Romeo and Juliet, Richard III, Hamlet, Othello, Twelfth Night, The Merry Wives of Windsor or Macbeth. In all these theatrical representations, Dutt always performed the leading roles: he played Richard in Richard III, Othello in Othello or Brutus in Julius Caesar. Inspired by the IPTA (the People's Theatre Association), The Little Theatre Group was committed to left-wing ideological positions, which put into jeopardy their strong commitment to Shakespearean plays. For instance, when the Communist Party of India was forbidden, they penned a political article protesting against this action which was accompanied by a fragment of Romeo and Juliet. Miriam Stark, the leading actress, asked the following question: "If we really believe what we've written, then why are we staging the classics and for whom really?" The main dissatisfaction inherent in the group was related to their target audience, the westernized intellectuals of Calcutta instead of addressing the Indian proletariat. If they wished to stage plays for working-class audiences, the enactment of the plays ought to be in Bengali since they realised the impossibility of defending their left-wing political ideas and occasionally radical views if they only did productions for a minority audience. ${ }^{9}$ Mass audiences were unable to follow what was happening on the stage due to the language used. Obsessively concerned with the masses, Utpal Dutt detached from a theatre full of nuances of characterization, and projected a theatre with action to the full, and with an emphasis on expressions, entrances and exits. The beginning of his experiment was simply at the early stages.

\footnotetext{
${ }^{9}$ Obviously, the non-Bengali members of the group abandoned the company, and were replaced by other Bengali members. Many of the non-Bengali members came from Westernized Jewish families. Their background and education was British, whereas their status was Indian. Due to their loyalty to the English language, their departure was compulsory. Some of them went to Australia, while some others went to Israel.
} 
For Shakespeare's Quartercentenary, Utpal Dutt directed Julius Caesar (April 1964, Minerva Theatre), ${ }^{10}$ Romeo and Juliet (24 April 1964, Minerva Theatre) and A Midsummer Night's Dream (24 April 1964, Minerva Theatre) in Bengali. ${ }^{11}$ "Doing Shakespeare in Bengali is an experiment in itself. One should not venture anything beyond that. To do it the way Shakespeare wrote it, plain and simple, that was the safest" (Dutt in Paul 2006:15), claimed the theatre director when asked about experimenting with Shakespeare. The re-playing of Shakespeare in Bengali for the common man was categorized by Tapati Gupta (2010:158) as the phase of translation and localization. In spite of the fact that Dutt's predecessors believed strongly in "tradaptations," i.e. extremely free translations with a considerable number of alterations, Dutt made an effort not to make many changes. Nevertheless, some localization was necessary. The constant paradox and irony of Utpal Dutt's Bengali productions were that the characters spoke an Indian language, while they still retained the original Shakespearean names and wore Western costumes. In the words of Tapati Gupta: "Dutt's Bengali Shakespeares' might be seen as contextualizing the global in the local and reversing the process of subjugating the local to the global" (Gupta 2010:161). Therefore, instead of locality being eclipsed by globalization, these Bengali Shakespeares emerge solely as an instance of "glocalization."

Utpal Dutt's Bengali Romeo and Juliet (1964) was interestingly based on his own translation of the Shakespearean play. ${ }^{12}$ As in the rest of Dutt's Bengali Shakespeares, this production preserved the

\footnotetext{
${ }^{10}$ The Minerva Theatre was built in Calcutta in 1893 . The opening play was Macbeth. In fact, the history of the theatre has always been closely associated with Shakespeare's plays, for a large number of them were staged there. After being burnt down in a fire in 1922, the theatre acquired a reputation as a jinxed and unlucky theatre. The Minerva Theatre was renovated again in 1925, and could still be the venue of a large number of theatre performances.

${ }^{11}$ There is no available information regarding Dutt's Bengali A Midsummer Night's Dream. The reason for this may be that the performance was not a failure, but did not succeed either. It is also worth noticing that Utpal Dutt's 'Bengali Shakespeares' have not received as many positive reviews as his English adaptations.

${ }^{12}$ Apart from Utpal Dutt's 1964 theatre productions, there were other adaptations to commemorate Shakespeare's birth such a Hindi King Lear directed by Ebrahim Alkazi, a celebrated director of Delhi's National School of Drama (NSD). See the bibliography "Shakespeare in India" at the website Internet Shakespeare editions.
} 
original place names as well as the names of the dramatis personae. Furthermore, the costumes were period and the scenery was conventional. Utpal Dutt's main aim was to recreate the Elizabethan playhouse within the proscenium. In his Romeo and Juliet, there was a large set and an "apron" in front of the curtain on which the Mantua scenes were acted accelerating the speed of the action. One of the notable changes in Dutt's production concerns Friar Laurence. The Friar's commonness - he escapes, he does not confess - rather than his good purposes is highlighted. "He is a failed pastor unable to protect his protégés from an insensitive Establishment. Dutt made the character fit into his ideological framework but took his cue from Shakespeare" (Gupta 2005:3). Other consistent differences include the considerable reduction of slang - basically in the nurse's speeches - the transposition of Verona and Mantua to a small Bengali town with a middle-class system, and the abuse of everyday language in practically all the speeches. Characteristic of Utpal Dutt's Romeo and Juliet - as perhaps the clearest Western influence is the music used in the performance. Throughout the production, Tchaikovsky's music is constantly heard and overheard to make up for the loss of rhyming couplets and sonnet sequences in the translated version. Utpal Dutt is still reluctant to deprive the Shakespearean work of one of its best known cultural manifestations; Western music is impressed on this revolutionary project. ${ }^{13}$ The music provided an "occidental" or Western flavour rather than a Mediterranean taste. But Tchaikovsky's music is interestingly mixed with Dutt's troupe's own compositions - which were heard in the interludes. The thrust of Utpal Dutt's argument was to make clear "to the audience that a foreign dramatist was being domiciled" (Gupta 2010:163). Moving from the global to the local, from the unknown to the known world, from West to East, Utpal Dutt with his Bengali Romeo and Juliet started to conceive his plan of the decolonization of the Bard.

Even if Utpal Dutt placed great emphasis on the fact that when Shakespearean plays were translated into Bengali, no other changes

\footnotetext{
${ }^{13}$ The influence of Tchaikovsky's orchestral work on an "Eastern" Romeo and Juliet's afterlife can be seen in Qing ren jie (aka A Time to Love, dir. Jiangi Huo, 2005). In this adaptation, the leading couple is modeled on the famous Shakespearean characters. Curiously enough, the production toys with other Western cultural manifestations based on Romeo and Juliet, such as Franco Zeffirelli's Romeo and Juliet (1968).
} 
should be made (Dutt in Rajinder 2006:15), a newer dimension was suggested in his production of Julius Caesar, staged in modern costume in a Bengali translation by Jyotirindranath Tagore in 1964 with a fascist Italy backdrop. ${ }^{14}$ The picture of politics contained in the work might easily appear as allusions to the convoluted political life India was going through. 1964 was marked by Nehru's death the first Prime Minister of the postcolonial era - the power vacuum left in India after his death and by the split within the Communist Party. In this production, Utpal Dutt amalgamated the past and present. He and his company "interpreted Julius Caesar somewhat predictably as a study of fascism, with Caesar appearing as a timeless dictator, Antony a Fascist orator, and Cassius an extremist revolutionary" (Bharucha 1983:57). Thus, like Utpal Dutt's English theatrical productions of Julius Caesar, this Bengali adaptation described Caesar and Anthony as Fascists, Marcus Brutus as a Socialist and Cassius and the others as Communists. For Gupta (2005:3), the personality of Dutt's Caesar was curiously merged with "Hitler's, in the garb of Chaplin's Dictator." Immediately revealed by Utpal Dutt was the intention to disturb the audience by exposing them to Shakespeare in Bengali and to a cast wearing modern dress and military uniforms instead of Roman togas. In spite of its resemblance to Orson Welles' well-known 1937 production (Death of a Dictator), which "would influence performances of the play on both sides of the Atlantic for a long time" (Calvo 2010:505), this representation of Julius Caesar was an independent choice. In an interview with Samik Bandyopadhyay, Utpal Dutt denied any influence from this production, arguing his lack of knowledge of Orson Welles at the time (Bandyopadhyay in Paul 2006:10). Although Utpal Dutt's Bengali Julius Caesar was a faithful literal translation, some changes were made. For instance, the comparison of Caesar to Colossus did not appear. "Glocalization" or "transculturation" would be explicitly present via modes of address. In Act II scene IV, "the way Lucius addresses Calpurnia would remind the Indian audience of a Bengali landed aristocrat's wife being addressed by a vassal" (Gupta 2005:3). Consequently, as in Romeo and Juliet's production, Utpal Dutt's Julius Caesar underwent a

\footnotetext{
${ }^{14}$ Utpal Dutt also produced theatre adaptations of Julius Caesar in English in modern dress. All his productions of Shakespeare's Julius Caesar were played before urban audiences.
} 
process of "glocalization" by bringing together the Bengali language with a western ambiance. At this stage in Utpal Dutt's professional career, his 1964 Romeo and Juliet and Julius Caesar are in-between, hybrid projects which would become extremely more radical over the years. Yet, taking into account the considerable degradation and decline of performances in Shakespeare's étage terrible in India, Utpal Dutt's productions of Shakespeare's plays are a significant contribution to the re-emergence of Shakespeare on the Indian stage as well as to his indigenization.

\section{Conclusion}

This paper has argued that there is an interesting twist in the reception of Shakespeare in India in 1964. First of all, after a period of absence, there is a considerable rebirth of interest in Shakespeare with publications and stage productions. Unlike the 1916 Tercentenary, the 1964 Quartercentenary was widely celebrated and commemorated in India. Besides the special issue of Indian Literature devoted to Shakespeare, which records in great detail the performances of Shakespeare's plays in the different Indian theatres, Utpal Dutt's Bengali Shakespearean productions signal the "Indianization" of Shakespeare. Following Arjun Appadurai's theoretical framework of the "decolonization of cricket," this paper has demonstrated that it was necessary to remove the English language to transform a typical colonizer's text into an amended and localized version. The rise of an Indian Shakespeare in vernacular language in 1964 took place around the same time that India saw the end of the leadership of Prime Minister Nehru, associated with the independence movement, and when the split inside the Communist Party announced a radicalization of Indian politics and a move towards a stronger rejection of Western capitalism. If the "vernacularization" of Shakespeare on the Indian stage started in 1964, it reached its apogee in 1970 thanks to Utpal Dutt again, with his Macbeth in the jatra folk tradition - a popular form of Bengali theatre - that constitutes an attack on Indira Gandhi's regime. ${ }^{15}$ In

\footnotetext{
${ }^{15}$ In Re-playing Shakespeare in Asia, Tapati Gupta explores in depth Utpal Dutt's Romeo and Juliet in the jatra tradition. In this chapter, the author compares three very different Romeo and Juliet performances by Utpal Dutt (in English, in Bengali and in
} 
addressing the way the four-hundredth anniversary of Shakespeare's birth was celebrated in India, this article contributes significantly to the history of Shakespeare reception and commemoration. The year 1964 in India then witnessed an important step in the decolonization of Shakespeare and the construction of Shakespeare as an Indian cultural icon, one that satisfied local exigencies and whose world could be successfully rebuilt in the villages of Bengal.

\section{References}

Anzai, Tetsuo, Soji Iwasaki and Peter Milward eds. 1999. Shakespeare in Japan. Lewiston, N.Y.: Edwin Mellen.

Appadurai, Arjun 1996. Modernity at Large. Minnesota: University of Minnesota Press.

Bhabha, Homi 1994. The Location of Culture. London and New York: Routledge.

Bharucha, Rustom 1983. Rehearsals of Revolution: The Political Theater of Bengal. Hawaii: Hawaii University Press.

Bhattacharya, S. K. 1964. "Shakespeare and the Bengali Theatre." Indian Literature 7: 27-40.

Calvo, Clara 2010. "Commemorating Shakespeare and Wartime Europe: Julius Caesar in 1916." Ed. Antonio Moreno Hernández. Julio César, Textos, Contextos y Recepción: de la Roma Clásica al Mundo Actual. Madrid: Universidad Nacional de Educación a Distancia: 493-506.

Dutt, Utpal 1999 (1964). "Taking Shakespeare to the Common Man." Epic Theatre (1999): 19.

Gupta, Somanatha 2005. The Parsi Theatre: Its Origins and Development. Edited and translated by Kathryn Hansen. Calcutta: Seagull books.

Gupta, Tapati 2005. "Utpal Dutt's Plays." Muse India: The Literary Journal 4.

<url: http://www.museindia.com/viewarticle.asp?myr=2005\&issid= 4\&id=124>. Last accessed 03/10/2011.

— 2010. "From Proscenium to Paddy Fields: Utpal Dutt's Shakespeare Jatra." Eds. Poonam Trivedi and Minami Ryuta. Re-playing Shakespeare in Asia. New York and London: Routledge: 157-180.

the jatra tradition), 157-180. For Jatra Shakespeare performances, see also Kapadia (2008:91-104). 
(3) ederi 22 (2012)

Huo, Jiangi, dir. 2005. Qing ren jie (aka A Time to Love). Perf. Wei Zhao and Yi Lu. PKU Starlight Group, Starlight International Media. Film.

Indian Literature, Journal of the Sahitya Akademi or Academy of Letters, Delhi, 7.1, 1964.

Ivory, James dir. 1965. Shakespeare Wallah. Perf. Geoffrey Kendal, Sashi Kapoor, Felicity Kendal, Jennifer Kendal, Geoffrey Kendal, Laura Kendal, Madhur Jeffrey and Utpal Dutt. Merchant Ivory Productions. Film.

Kapadia, Parmita 2008. "Jatra Shakespeare: Indigenous Indian Theater and the Postcolonial Stage." Eds. Craig Dionne and Parmita Kapadia. Native Shakespeares: Indigenous Appropriations on a Global Stage. Surrey: Ashgate: 91-104.

Kendal, Geoffrey 1986. The Shakespeare Wallah: The Autobiography of Geoffrey Kendal/with Clare Colvin, Introduction by Felicity Kendal. London: Sidgwick \& Jackson.

Lal, Ananda ed. 2009. Theatres of India. New Delhi: Oxford University Press.

Lanier, Douglas 2012. "Marketing." Ed. Arthur F. Kinney. The Oxford Handbook of Shakespeare. Oxford: Oxford University Press: 499-515.

Levith, Murray 2004. Shakespeare in China. New York: Continuum.

Li, Ruru 2003. Shashibiya: Staging Shakespeare in China. Hong Kong: Hong Kong University Press.

Narasimhaiah, C. D. 1964. Shakespeare Came to India. Bombay: Popular Prakashan.

Olivier, Laurence dir. 1948. Hamlet. Perf. Laurence Olivier, Jean Simmons and John Laurie. Two Cities Films. Film.

Oxygen News, Special Shakespeare number. Kolkata. 1964.

Paul, Rajinder ed. 2006. Contemporary Indian Theatre: Interviews with Playwrights and Directors. New Delhi: Sangeet Natak Akademi, Hope India Publications.

Paul, Sunita 1989. A Tribute to Shakespeare. New Delhi: Theatre and Television Associates.

Sahu, Kishore dir. 1954. Hamlet. Perf. Mala Sinha, Pradeep Kumar and Kishore Sahu. Hindustan Chitra. Film.

Sen, Aparna, dir. 1981. 36 Chowringhee Lane. Perf. Jennifer Kendal, Dhritiman Chatterjee and Debashree Roy. Film-Valas. Film.

Singh, Jyotsna 1996. Colonial Narratives: Discoveries of India in the Language of Colonialism. London: Routledge.

Sisson, Charles 1926. Shakespeare in India: Popular Adaptations on the Bombay Stage. London: The Shakespeare Association. 
Trivedi, Harish 1995. Colonial Transactions: English Literature and India. Manchester: Manchester University Press.

Trivedi, Poonam and Dennis Bartholomeusz eds. 2006. India's Shakespeare: Translation, Interpretation and Performance. New Delhi: Pearson Longman.

Zefirelli, Franco dir. 1968 Romeo and Juliet. Perf. Leonard Whiting, Olivia Hussey, John McEnery, Milo O'Shea and Pat Heywood. BHE Films, Verona Produzione, Dino de Laurentiis Cinematografica. Film.

\section{Web Resources}

Shakespeare in India - Bibliography (at Internet Shakespeare editions website): url: http://internetshakespeare.uvic.ca/Library/Criticism/shakespearein/i ndia7.html (Last accessed 07/08/2011).

How to cite this article:

García-Periago, Rosa M. "The re-birth of Shakespeare in India: celebrating and Indianizing the Bard in 1964." SEDERI 22 (2012): 51-68.

Author's contact: rosagperiago@um.es 